\title{
Tagging Results from the 2000-2004 Federal Experimental Fishery for Atlantic Halibut (Hippoglossus hippoglossus) in the Eastern Gulf of Maine
}

\author{
J. Kohl Kanwit \\ Maine Department of Marine Resources, P. O. Box 8, \\ West Boothbay Harbor ME 04575, U.S.A. \\ E-mail: kohl.kanwit@maine.gov
}

\begin{abstract}
Kanwit, J. K. 2007. Tagging Results from the 2000-2004 Federal Experimental Fishery for Atlantic Halibut (Hippoglossus hippoglossus) in the Eastern Gulf of Maine. J. Northw. Atl. Fish. Sci., 38: 37-42. doi:10.2960/J.v38.m594
\end{abstract}

\begin{abstract}
Tagging results from five years of a federal experimental Atlantic halibut fishery in the eastern Gulf of Maine are presented in this paper. These data show both localized movements within the study area and long-distance emigrations of juveniles. Twenty-eight percent of the recoveries from this study were made in Canadian waters, demonstrating an interchange between fish in the Gulf of Maine and those considered part of the Scotian Shelf/Southern Grand Banks stock unit. The predominance of long-distance, northeastward movement of juveniles poses the question of compensatory emigration in response to the predicted southwestward drift of eggs and larvae.
\end{abstract}

Key words: Atlantic halibut, compensatory migration, emigration, movement, tagging

\section{Introduction}

Atlantic halibut (Hippoglossus hippoglossus) are found in the boreal and subarctic waters of the Atlantic Ocean. Considered a nuisance species in the Gulf of Maine during colonial times, halibut were not targeted commercially until the early nineteenth century (Collette and Klein-MacPhee, 2002). However, by the 1940s the stock had collapsed and was considered "commercially extinct" with annual landings averaging less than 100 metric tons (t) after 1953. A targeted fishery did not occur in the Gulf of Maine between the mid and late twentieth century, resulting in a severe lack of data. Atlantic halibut catches in federally regulated US waters currently are limited to bycatch levels (one fish per trip) incidental to the targeted groundfish fishery. A small but directed fishery in Canadian waters has provided opportunities for several studies exploring life history parameters, population dynamics and the ecology of Atlantic halibut (McCracken, 1958; Kohler, 1964, 1967; Bowering, MS 1986; Zwanenburg and Wilson, MS 2000). In contrast, virtually nothing is known about the current stock structure of the Atlantic halibut population in US waters (Trumble et al., 1993); however there is consensus that the stock is depleted to historically low levels of biomass (Brodziak and Col, MS 2005). In an effort to improve the biological and life-history data available for Atlantic halibut, the Maine Department of Marine Resources (DMR) in cooperation with Maine Sea Grant and several commercial fishermen implemented a federal experimental fishery in 2000. The federal experimental fishery operated on an annual basis for two months each spring for five years. This project collected valuable biological information including length, weight, age, sex and maturity data, as well as movement data from the tagging component of the study. Some of these data were used in the first estimates of halibut life history parameters for fish found in US waters (Sigourney et al., 2006).

This paper focuses on describing the tag return data resulting from the Atlantic halibut federal experimental fishery. Over the course of the experimental fishery, 825 halibut were tagged and, as of 31 December 2005, 92 had been recaptured. The resulting data indicated both smallscale seasonal movements and long-distance emigrations similar to observations from other studies (Kohler, 1964; Stobo et al., 1988). These data appear consistent with the hypothesis of long-distance, compensatory emigration 
designed to mitigate larval drift and more seasonal, localized migrations within spawning/feeding areas (Skud, MS 1977; Stobo et al., 1988).

\section{Materials and Methods}

\section{Data and Sample Collection}

This project was conducted under the terms of an Exempted Fishing Permit (EFP) issued by the National Marine Fisheries Service (NMFS) Northeast Regional Office. Starting in the year 2000, between three and six fishermen were permitted to fish for Atlantic halibut in an area along the eastern coast of Maine (Fig. 1). The EFP was issued annually for five years (2000-2004) with a defined fishing season that lasted for two months and had varying start dates between April and mid-May. An overall Total Allowable Catch (TAC) limit was determined by the NMFS Regional Administrator as part of the annual permitting process. Participating fishermen were required to use longline hook gear (often referred to as tub trawls) with $14 / 0$ or larger circle hooks. They were limited to a 700 hook maximum, however the configuration of the hooks was not specified. Circle hooks were selected for this study due to evidence showing reduced injury and mortality in comparison to fishing with conventional J-hooks (Kaimmer and Trumble, MS 1997; Cooke and Suski, 2003). Participating fishermen were required to maintain detailed daily logbooks designed by the principal investigator. The federal minimum size regulation of 36" $(91.4 \mathrm{~cm})$ was applied to all retained Atlantic halibut. All tagged fish were measured and marked using a plastic coated wire tag inserted through the first operculum by a specialized stainless steel needle. This "wire spaghetti" tag and application method were adopted from the International Pacific Halibut Commission (IPHC) tagging program due to the tag's low shedding rate and high visibility (Kaimmer and Trumble, 1998). The tags were $16.0 \mathrm{~cm}$ long with a $7.5 \mathrm{~cm}$ yellow plastic section inscribed with: "H00001 Return to DMR // PO Box 8 W Boothbay Hbr, ME 04575 PH: 207-633-9535". Tags from 2000 and 2001 were manufactured by Floy Tag Inc. and by Hallprint Pty Ltd. between 2002 and 2004. Fishermen were trained on proper tagging techniques and handling protocols before the start of each fishing year. Tagging mortality was not directly assessed in this study, however Peltonen (MS 1969) reported an instantaneous tagging mortality rate of 0.158 per year for Pacific halibut.

Tag returns were encouraged outside of the experimental fishery through an outreach effort focused on Maine state waters halibut fishermen, the US groundfish fleet and the Canadian halibut longline fleet through

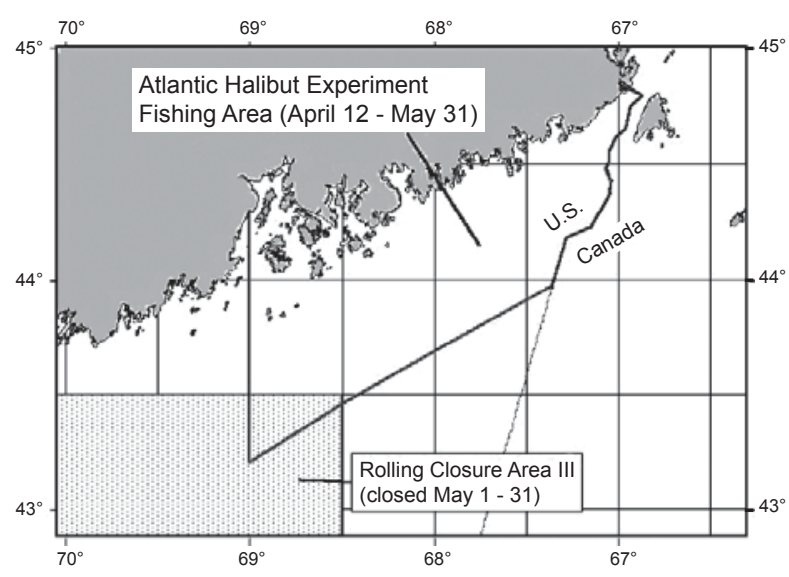

Fig. 1. Atlantic halibut experimental fishing area in Gulf of Maine, USA.

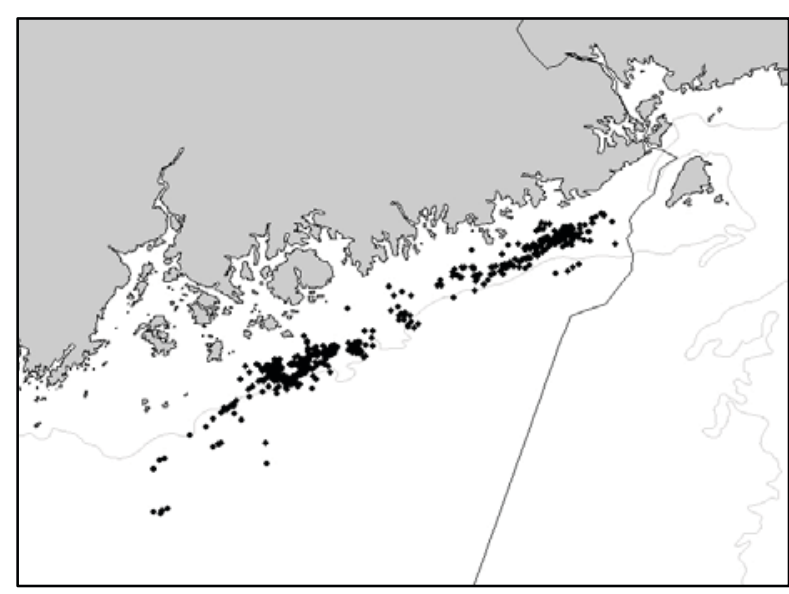

Fig. 2. Atlantic halibut tag release locations in 2000-2004.

posters and publications. Individuals returning tags were sent an informational package on the program and their particular recapture along with a baseball hat. The quality of the return data was consistent with $99 \%$ of recaptures reported with information on a specific fishing ground and $85 \%$ reported with exact coordinates. With only two exceptions, the reported recapture date was the actual day the fish was caught.

\section{Analyses of Recapture Data}

Analyses were limited to descriptive statistics and general movement trajectories due to the nature of the data collected. Only return data with complete information were used in the analyses, resulting in the removal of two records $(\mathrm{N}=90)$. Tag returns were plotted using Geographic Information Systems (GIS) software and distances and bearings were calculated. The recovered halibut were split into two groups, fish that traveled less 
than $50 \mathrm{~km}$ and fish that traveled greater than or equal to $50 \mathrm{~km}$. These divisions were made to identify small-scale versus large-scale movements. Average trajectories and magnitude of east $\left(0-180^{\circ}\right)$ and west $\left(181-360^{\circ}\right)$ movement from a common release site were calculated for both groups. Minimum and maximum trajectories from the point of origin were also calculated for each group. The relationship between distance traveled and length at release was explored using cluster analysis on the natural $\log$ of distance traveled by month. It is difficult to determine the sex of live halibut, so this information was not collected for released fish, precluding any sex specific analyses. A distinction was made between immature and mature halibut based on the median length at maturity of $103 \mathrm{~cm}$ proposed in Sigourney et al. (2006). All tagged fish were less than $103 \mathrm{~cm}$ and were therefore considered immature for the purposes of the analyses presented in this paper.

\section{Results}

A total of 598 trips were made during the five years of the experimental fishery. 1520 individual sets were made, totaling 145000 hooks fished. Of the 2607 halibut caught, 1611 fish were retained and 996 were released. In all, $23 \%$ of the released fish were not tagged due to the condition of the fish or an insufficient supply of tags. Over the course of the experimental fishery, 825 halibut were tagged and released (Fig. 2). The tagged fish averaged $79 \mathrm{~cm}$ (Fig. 3, Table 1). Occasionally, larger fish

TABLE 1. Mean, median and standard deviation of length at release, time at large and distance traveled.

\begin{tabular}{lccc}
\hline & $\begin{array}{c}\text { Length } \\
(\mathrm{cm})\end{array}$ & $\begin{array}{c}\text { Time } \\
(\text { days })\end{array}$ & $\begin{array}{c}\text { Distance } \\
(\mathrm{km})\end{array}$ \\
\hline Mean & 79 & 431 & 151 \\
Median & 81 & 384 & 12 \\
Standard Deviation & 6.67 & 335.05 & 323.00 \\
\hline
\end{tabular}

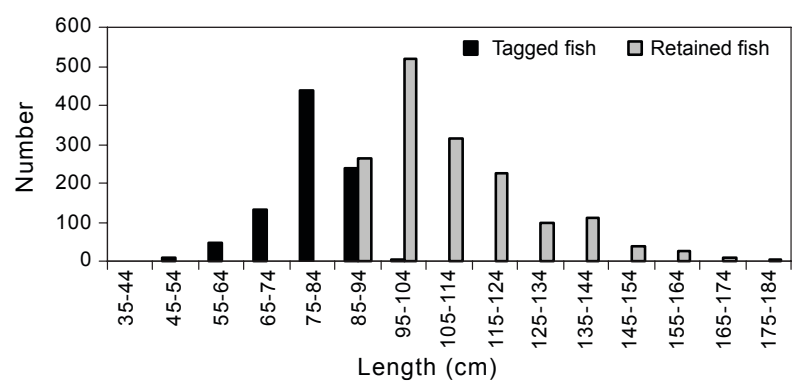

Fig. 3. Size distribution of tagged and retained Atlantic halibut. were tagged toward the end of the season when daily catch limits were implemented (i.e. four fish per day after an individual seasonal TAC of 50 fish, Maine Department of Marine Resources, 2003).

A total of 92 tagged halibut were recovered representing an $11 \%$ unadjusted return rate. Tag releases and recoveries varied by year of the experimental fishery and latent recoveries are still being reported. Some fish were recovered after only one day at large while other fish were recovered up to 1460 days after release. The average time at large was 431 days and there was no relationship between length at release and time at large $(p=0.22)$. The distribution of recoveries ranged from within the experimental fishing area along the eastern coast of Maine to the west coast of Newfoundland and the Grand Banks (Fig. 4). In all, 68\% of the recaptures were made within the study area traveling an average of $9 \mathrm{~km}$ (Fig. 5). The remaining $32 \%$ of recaptures were made between 50 and $1758 \mathrm{~km}$ from their release locations. Recoveries were dominated by east-west movements, illustrated by Fig. 6. Some $70 \%$ of the fish captured near their release location moved west and $90 \%$ of the fish were recaptured more than $50 \mathrm{~km}$ from their release location moved in an easterly direction. There was not a significant relationship between length at release and the natural log of distance traveled per month ( $p=0.90$; Fig. 7). There appeared to be a division between short-distance and longdistance movements so a K-means test using Systat 11 (Systat Software Inc, USA) was run using two groups. A significant difference was found between the two groups $\left(F\right.$-ratio $=323 ;$ d.f. $\left._{1,2}=1,85 ; p<0.05\right)$.

Project participants were responsible for $65 \%$ of the recaptures. The remaining recaptures were made

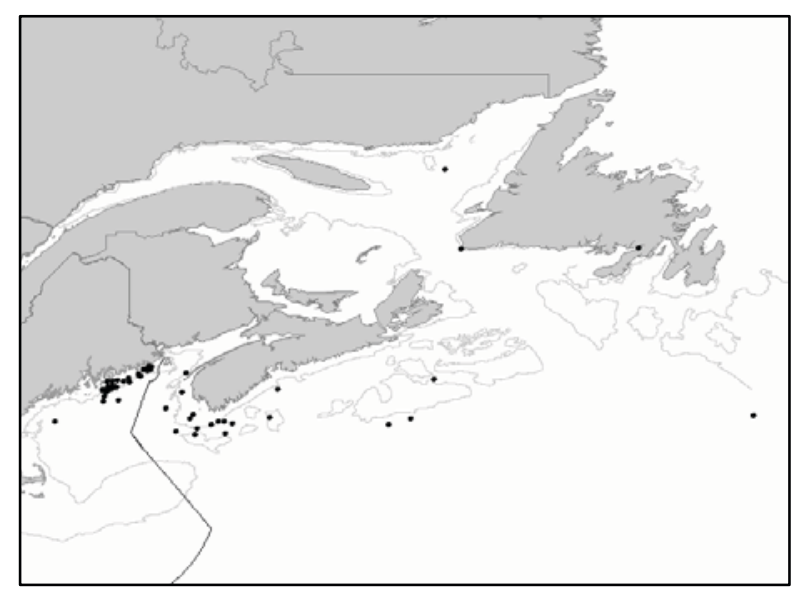

Fig. 4. Recapture locations of tagged Atlantic halibut. 


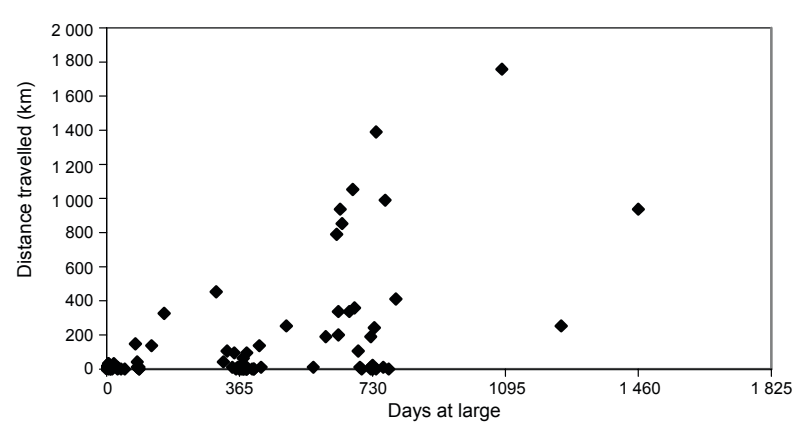

Fig. 5. Distance traveled and duration between release and recapture.

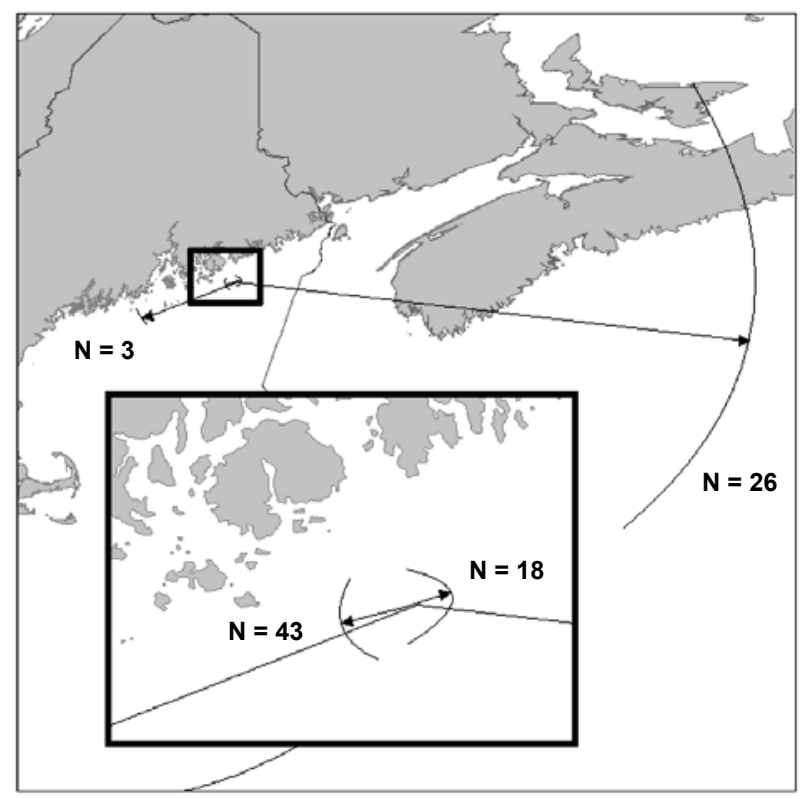

Fig. 6. Average east-west movement of fish recaptured $<50$ $\mathrm{km}$ from release site (map inset) and $\geq 50 \mathrm{~km}$ from release site. The arcs represent all possible trajectories between the minimum and maximum bearing observed for each group.

by participants in the Maine state waters fishery (5\%), the US commercial trawl fishery (2\%) and the Canadian hook and gillnet fisheries (28\%). High reward tags were not used in this study so there was no estimate of reporting rate among the recovery sectors.

\section{Discussion}

Tagging results from the federal experimental fishery provide an initial insight into the movement patterns for Atlantic halibut found off the eastern coast of Maine. These data indicate seemingly contradictory patterns of extensive emigrations and limited dispersal within the

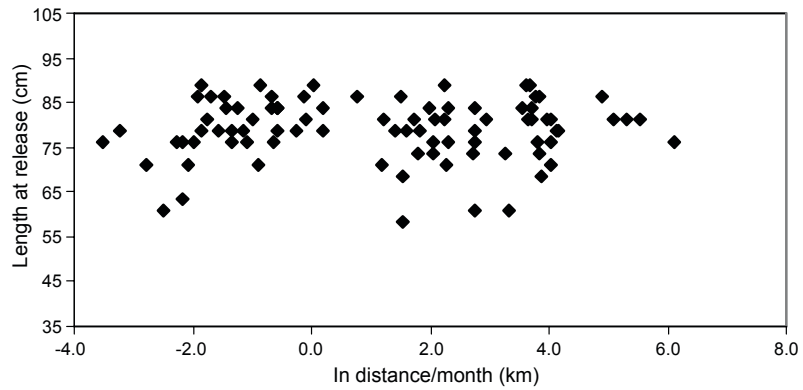

Fig. 7. Distance traveled per month between release and recapture for different sizes of Atlantic halibut.

study area. A similar pattern of recoveries was observed in Pacific halibut tagging data, causing Skud (MS 1977) to pose the question: "How do stocks maintain their geographic position when ocean currents carry eggs and larvae away from the spawning grounds, particularly when the magnitude of compensatory movement by adults apparently cannot account for the "loss" of these early life stages?"

Skud (MS 1977) concluded that most of the compensatory emigration of Pacific halibut takes place at the juvenile rather than at the adult phase. This movement explains how stocks are perpetuated in areas where the eggs and larvae are dispersed long distances away from the spawning areas. These findings were reinforced by Blaylock et al. (2002) who found that juvenile Pacific halibut do not have discrete parasitic compositions, suggesting that in the juvenile phase Pacific halibut occupy mixed stock nursery areas. Evidence of discrete parasitic compositions in adults, however indicated that the juveniles must home to spawning areas. Stobo et al. (1988) concluded that the extent of Atlantic halibut emigration is inversely related to maturity, although they were unable to specifically test the compensatory movement hypothesis due to a lack of egg and larval data. Interestingly, Stobo et al. (1988) observed a tendency for fish released on the Scotian Shelf to move to the northeast while fish from the Grand Banks region showed no preferred direction of movement.

All of the fish tagged in this study were immature, precluding a comparative analysis of movements of mature fish versus immature fish. The size range of tagged fish was constrained by the gear which selected for fish greater than $38.1 \mathrm{~cm}$ and the fishery regulations that allowed retention of fish larger than $91.4 \mathrm{~cm}$ (Maine Department of Marine Resources, 2003). The tagged and released fish were in the 66 and $99 \mathrm{~cm}$ size range, and were therefore immature. Despite this sampling bias, 
our data shows that there is still a pattern of both long distance emigrations and local seasonal migrations. This information suggests that some juveniles might exhibit compensatory emigration while some juveniles remain within their respective stock areas where they eventually reach maturity. Like Stobo et al. (1988), the compensatory emigration hypothesis cannot be tested due to lack of data on the dispersal of halibut eggs and larvae in the Gulf of Maine. However, the anticipated dispersal pattern of juveniles would be to the northeastward in contrast to the southwestward drift of eggs and larvae originating from the Scotian Shelf/Southern Grand Banks stock unit. This pattern is shown by our data where 26 of the 92 recaptures $(28 \%)$ in this study exhibited large-scale northeasterly emigrations into Canadian waters. There was no evidence of halibut returning to the Gulf of Maine after undertaking these long-distance emigrations although we only have two multiple recapture events. There is also no information on tagged fish released in the Scotian Shelf/Southern Grand Banks area being recaptured in the Gulf of Maine. If the juvenile compensatory emigration theory proposed by Skud (MS 1977) in the Pacific also applies to northwest Atlantic halibut, future tagging of mature fish $(>103 \mathrm{~cm})$ in the Gulf of Maine should result in local recaptures between their spawning and feeding grounds.

There are several limitations and potential biases to the data gathered in this study. All recoveries were dependant on commercial fisheries in four distinct sectors: the experimental fishery, the Maine state waters fishery, the US bottom trawl fishery and the Canadian fishery. Two of these fisheries were restricted by a regulatory season, therefore recaptures from these fisheries could only occur while they were permitted to operate. This seasonality is likely the cause of the annual recapture clusters around the 365 and 730 day markers seen in Fig. 5. There was also a regulatory geographic limitation on recoveries and catch restrictions ranging from seasonal to daily trip limits and minimum sizes $(91.4 \mathrm{~cm}$ for the US and $81.3 \mathrm{~cm}$ for Canada). The minimum size potentially affected recaptures, illustrated by a case where a fisherman threw back a tagged sublegal halibut in Newfoundland without recording the tag number. This same fisherman did record and report a tag on a legal size fish he recaptured and retained a few days later. All of the fisheries were quota based, resulting in varying degrees of fishing effort which influenced the number of recaptures.

Twenty-eight percent of the recaptured halibut were recovered in Canadian waters ranging from the Bay of Fundy to the Gulf of Saint Lawrence, Newfoundland and the Southern Grand Banks. While this high return rate from Canadian waters might be due to fishing effort and differential reporting rates, it is an important finding. The observed tag returns demonstrate that there is interchange between fish in the Gulf of Maine and those considered part of the Scotian Shelf/Southern Grand Banks stock unit. These results have significant implications for management of the fishery. More comprehensive tagging work should be undertaken in an effort to estimate the emigration rates of juveniles from the Gulf of Maine to the Scotian Shelf/Southern Grand Banks and validate seasonal migrations of mature fish.

\section{Acknowledgments}

I would like to thank the participating fishermen and Chris Bartlett from Maine Sea Grant for initiating the EFP process and facilitating this research. Without the cooperation of the Maine Department of Marine Resources and the NMFS Northeast Regional Office this work would have been impossible. Finally, I appreciate the comments and suggestions of Dr. Jon Brodziak, formerly of the Northeast Fisheries Science Center.

\section{References}

BLAYLOCK, R. B., L. MARGOLIS, and J. C. HOLMES. 2002. The use of parasites in discriminating stocks of Pacific halibut (Hippoglossus stenolepis) in the northeast Pacific. Fish. Bull., 101: 1-9.

BOWERING, W. R. MS 1986. The distribution, age and growth and sexual maturity of Atlantic halibut (Hippoglossus hippoglossus) in the Newfoundland and Labrador area of the Northwest Atlantic. Can Tech. Rep. Fish. Aquat. Sci., No. $1432,34 \mathrm{p}$.

BRODZIAK, J., and L. COL. MS 2005. Atlantic halibut. In: Assessment of 19 northeast groundfish stocks through 2004. NEFSC Ref. Doc. 05-13, 499 p.

COLLETTE, B. B., and G. KLEIN-MACPHEE. 2002. (eds.).Bigelow and Schroeder's Fishes of the Gulf of Maine. $3^{\text {rd }}$ ed. Smithsonian Institution Press, Washington, D.C. p. 569-572.

COOKE, S. J., and C. D. SUSKI. 2004. Are circle hooks an effective tool for conserving marine and freshwater recreational catch-and-release fisheries? Aquatic Conserv: Mar. Freshw. Ecosyst., 14: 299-326. doi:10.1002/aqc.614

KAIMMER, S. M., and R. J. TRUMBLE. MS 1997. Survival of Pacific halibut released from longlines: hooking location and release methods. In: Proceedings of Fisheries Bycatch: Consequences and Management. Fairbanks, Alaska. Alaska Sea Grant Report 97-02, p. 101-105.

1998. Injury, condition, and mortality of Pacific halibut bycatch following careful release by Pacific cod and sablefish fisheries. Fish. Res., 38: 131-144. doi:10.1016/ S0165-7836(98)00153-2

KOHLER, A. C. 1964. Movements of halibut on the Nova Scotian and Grand Banks. J. Fish. Res. Board Can., 
21: $837-840$.

1967. Size at maturity, spawning season, and food of Atlantic halibut. J. Fish. Res. Board Can., 24: 53-66.

MAINE DEPARTMENT OF MARINE RESOURCES. 2003.

Rule Chapters for the Department of Marine Resources: Groundfish. Chapter 34.10(1)(B)(4)(b). http://www. maine.gov/sos/cec/rules/13/chaps13.htm

McCRACKEN, F. D. 1958. On the biology and fishery of the Canadian Atlantic halibut, Hippoglossus hippoglossus L. J. Fish. Res. Board Can., 15: 1269-1311.

PELTONEN, G. J. MS 1969. Viability of tagged Pacific halibut. Int. Pac. Halibut Comm. Sci. Rep., No. 52, 25 p.

SIGOURNEY, D., M. ROSS, J. BRODZIAK, and J. BURNETT. 2006. Length at Age, Sexual Maturity and Distribution of Atlantic Halibut, Hippoglossus hippoglossus L., off the Northeast USA. J. Northw. Atl. Fish. Sci., 36: 81-90. doi:10.2960/J.v36.m574
SKUD, B. E. MS 1977. Drift, migration, and intermingling of Pacific halibut stocks. Int. Pac. Halibut Comm. Sci. Rep., No. 63, 42 p.

STOBO, W. T., J. D. NEILSON, and P. G. SIMPSON. 1988. Movements of Atlantic halibut (Hippoglossus hippoglossus) in the Canadian North Atlantic. Can. J. Fish. Aquat. Sci., 45: 484-491.

TRUMBLE, R. J., J. D. NEILSON, W. R. BOWERING, and D. A. McCAUGHRAN. 1993. Atlantic halibut (Hippoglossus hippoglossus) and Pacific halibut (H. stenolepis) and their North American fisheries. Can. Bull. Fish. Aquat. Sci., No. 227, 84 p.

ZWANENBURG, K. C. T., and S. WILSON. MS 2000. The Scotian Shelf and Grand Banks Atlantic halibut (Hippoglossus hippoglossus) survey - Collaboration between the fishing and fisheries science communities. ICES C. M. Doc., 2000/W:20, 26 p. 